\title{
University for All Programs (ProUni): Engagement, Satisfaction, and Employability
}

\author{
Vera Lucia Felicetti ${ }^{1}$ \\ ${ }^{1}$ Graduate Program in Education, La Salle University, Canoas - Rio Grande do Sul, Brazil \\ Correspondence: Vera Lucia Felicetti, Victor Barreto Avenue, Graduate Program in Education, Canoas n²288, \\ Centro CEP 92010-000 Rio Grande do Sul, Brazil. Tel: 55-51-3476-8677. E-mail: \\ vera.felicetti@unilasalle.edu.br
}

Received: February 17, 2017

Accepted: March 22, $2017 \quad$ Online Published: July 29, 2017

doi:10.5539/ies.v10n8p29

URL: https://doi.org/10.5539/ies.v10n8p29

\begin{abstract}
A training at Higher Education level needs, in addition to improve the skills specific in the area chosen, to develop a set of skills and/or personal attributes that make him or her more likely to succeed in the profession. In this context, this paper was developed and has the objective to identify the relationships between engagement, satisfaction, and employability of students who completed the university as University for All Program (ProUni) scholarship. This target group of students was chosen because of the importance of ProUni for the Advancement of Education policies of affirmative actions in Brazil. The ProUni gives scholarships to students from minority (underrepresented) groups to study at private universities, through the National Secondary Education Exam ENEM (Brasil, 2005). Among these groups are students who attend public high schools (a proxy for lower social class), low-income students, African Brazilian students, Indigenous Brazilian students, students with disabilities, and not graduated teachers that work in public elementary and secondary schools. The research involved 198 ProUni graduates invited to answer an online questionnaire. There were 134 respondents, $123(91.8 \%)$ were working since we were interested in employment, only these participants were included in the analysis. The results suggest that employability consolidates and reflects in the conquest of labor activity, as well as in graduate satisfaction with their training and job. These results are indicative of the engagement of the student with their learning, therefore with their graduate degree.
\end{abstract}

Keywords: graduate ProUni, engagement, employability, satisfaction

\section{Introduction}

Student engagement is a rarely studied topic in the Brazilian educational context (Felicetti and Morosini 2008). This claim was determined in 2008 through bibliometric research in the databases of the annual ANPED meetings (Associação Nacional de Pós-Graduação e Pesquisa em Educação) and in the CAPES (Coordenação de Aperfeiçoamento de Pessoal de Nivel Superior) databases of theses and dissertations regarding student engagement in learning.

At the time, the authors observed this topic indirectly in studies involving other objects of interest, including those developed in the organizational area. Moreover, few studies were identified regarding higher education graduates. The research by Felicetti and Morosini (2008) evidenced that, as implied by the papers read, engagement is much greater than commitment. The latter is related to and concerns everything that is done, while engagement constitutes what is done and how it is done, making it greater than commitment (Felicetti \& Morosini, 2008).

In terms of public policies, a set of affirmative actions for access to Higher Education has been growing in Brazil. The University for All Program - ProUni stands out among them and is aimed at granting full or partial study scholarships for students from public schools (or from private schools with a study scholarship) to study in private HEIs (Brasil, 2005). From 2005 to 2011, the program offered a total of 776,449 full scholarships and 606,867 partial scholarships, with a full total of 1,383,316 scholarships granted (SisProUni $2^{\circ} / 2011$ ). The ProUni scholarship is granted to students pre-selected according to scores on the National Higher Education Exam (ENEM) - and by their socioeconomic profile. Student engagement is an extremely important component of the success of ProUni as a policy of access and quality in higher education in Brazil. Thus, in the overlap between theory and reality, the research question that has guided this study is: what is the relationship between 
engagement, employability and satisfaction among ProUni students? The theoretical foundation investigated provided support for the research presented here, which, in addition to addressing ProUni student engagement, also addressed aspects such as employability and satisfaction of university graduates.

In this direction, this article presents a brief historical overview regarding the definition of student engagement, as well as aspects related to employability and satisfaction. Next, we provide an outline of statistical analyses involving the issue of engagement, employability and satisfaction, in addition to the academic performance and academic grade point average of ProUni graduates, seeing that they are indicators that are directly related to their engagement. Then, we point out the limitations found in the research and conclude with the final considerations followed by the references.

\section{Previous Literature}

The first perspectives on the topic of engagement date back to the middle of the last century and were aimed at the educational objectives associated to a set of possibilities capable of mediating in favor of behavioral changes in students. For Tyler (1949), the learning experience is related to the interaction between the student and the external conditions in the environment, thus leading to learning; that is, it is what the student does that leads to learning.

In the 1960s, Menne (1967) and Pace (1969) developed some studies on specific and observable measures of student behavior, including time spent on studying, participating in events or social activities held on campus. Pace (1979) showed that students gain more from their studies and other aspects of the university experience by investing more time and energy in educational tasks, such as: studying, interacting with their colleagues and professors and putting their learning into practice.

Astin (1984) popularized the concept "quality of effort" with his theory of involvement. It focuses on the active participation of students in their learning process, and encourages educators to focus more on what the student does and less on what they do. For Astin, student participation is related to the amount of physical and psychological energy that the student dedicates to the academic experience.

Pascarella (1985) studied the results of learning and cognitive development presented by students over the course of their university study. He pointed out aspects that reflect these results: structural and organizational characteristics of the teaching institution, student characteristics, professor and colleague interactions, and the quality of the effort put in.

Issues of social and academic integration in the university are seen by Tinto (1987), as paths that enable student retention in college; that is, these interactions increase students' engagement in their learning and, in extension, their retention in the teaching institution (Tinto, 2000; Pascarella \& Terenzini, 2005).

The studies by Chickering and Gamson (1987) present a set of good practices for University Education which enables new paths and perspectives for better learning, intensifying the effort and engagement of students and other participants in the educational process.

The term engagement, in more recent studies, is generally used to present constructs such as quality of effort and involvement in productive learning activities (Kuh et al. 2005; Kuh, 2009).

Harper (2008) observes engagement contributing to the psychosocial and social development of the student. This same author distinguishes engagement and commitment, exemplifying on the one hand that a student can be committed to a study group, but contributes, interacts, questions and advances little in his or her learning. On the other hand, the engaged student contributes intensely, interacts, questions and builds new knowledge (Harper \& Quaye, 2009). This example is compatible with the difference established by Felicetti and Morosini (2008). Commitment is related to everything that is done; that is, students can be a part of the teaching institution, but what they do, how they do it and how much they do is what constitutes their engagement, thus, it is much greater than commitment.

Engagement stands out as a collaborating factor for university adjustment. Cabrera, Nora and Castañeda (1992) indicate that educational funding can contribute to greater student engagement. Anaya (1996) and Baxter Magolda (1992), Pascarella and Terenzini (2005) perceive that engagement produces gains and benefits in students' cognitive development and mental skills. Ethnic and moral development is related to engagement, according to Evans (1987). Torres, Howard-Hamilton and Cooper (2003) emphasize psychosocial development, which contributes to issues of identity with respect to gender and race, providing a positive self-image.

Observe that the topic of engagement has been studied from various perspectives and by different researchers. This indicates that it is a broad and complex issue, which can be related to employability, success and 
satisfaction with the academic degree achieved. This relation is relevant, since students engaged in their learning can better develop the competences inherent to their specific degree, as well as a set of skills that better prepare them for the job market, including communication, teamwork, initiative and moral, aesthetic, ethnic aspects, among others (Felicetti, 2011).

In this direction, Knight and Yorke (2003, p. 5) write that employability corresponds to "A set of achievements, understandings and personal attributes that make individuals more likely to gain employment and be successful in their chosen occupation". Thus, employability can be understood with different cultural meanings (Arthur et al. 2008).

Higher Education graduates are expected to achieve the characteristics mentioned above through their education, since these graduates not only expect to obtain a job, but also a good salary (Teichler, 2007).

The job transition, work responsibilities and job quality vary according to the sociobiographical and educational characteristics of the graduates. Hence, experiences during the academic period, the competences acquired and job experiences also influence employability and the job itself (Schomburg \& Teichler, 2006). This implies, according to Hilsdorf (2008) that employability refers to a set of issues that encompass the personal development of employees and their competitive differentials with respect to other employees.

Students who better contemplate their education are adding attributes to their professional profile, which facilitates their placement in the job market, as well as contributes to satisfaction with respect to their profession. Job satisfaction, according to Robins (2005, p. 23), corresponds to a "set of emotions that one feels about one's job". Hence, satisfaction is understood as pleasure that results from the accomplishment of what was desired to be achieved; that is, it is contentment that comes from an action that needs to have meaning, functionality and utility.

According to De Vries, Cabrera, Vazquez and Queen (2008, p. 72), "there can be a variety of reasons for job satisfaction. They can vary from monetary aspects to personal aspects, the nature of the job, the economic sector, the type of program and the level of congruence between the college degree and the job". Thus, evaluating one's satisfaction is something broad, since it is the result of a complex sum of different elements.

The relation between job satisfaction and one's undergraduate degree is related to the monetary issue; that is, the higher the salary the greater the satisfaction (Pascarella \& Terenzini 2005; Vila, García-Aracil, \& Mora, 2007). In addition to the financial characteristics, Wolniak and Pascarella (2005), point out autonomy at work and personal development as factors that directly and indirectly influence job satisfaction.

According to Davis and Newstron (1992, p. 123), "job satisfaction can be regarded as an aspect of life satisfaction [...] job satisfaction also influences the feeling of one's general satisfaction with life". Thus, one's job is a relevant factor in the maintenance of one's quality of life. The relation between job, satisfaction and employability seems to be clear, since personal characteristics (employability) make individuals more likely to have jobs capable of living up to their expectations and making them satisfied with their chosen profession, as well as the salary that comes from it, since one cannot evaluate the quality of life in a job without considering the salary factor. Therefore, satisfaction is an excellent indicator of success, since it reflects upon monetary as well as non-monetary rewards (Vila, Garcia-Aracil \& Mora, 2007).

\section{Method}

The method used in this article is quantitative, observing frequencies and relations regarding the data collected (Booth, Colomb, \& Williams, 2000), which enabled the identification of the relations between engagement, employability and satisfaction of the ProUni graduates. The technical procedure used was ex post facto which enabled the analysis of the academic, professional, economic development and satisfaction of the graduates (Kerlinger, 1984).

With respect to the sampling process, this research was carried out with graduates from a nonprofit HEI in the state of Rio Grande do Sul, specifically, a group of 492 students entering via the University for All Program ProUni in 2005. The information analysis regarding the incoming students was carried out in July 2010. At that time, of the 492 incoming students in 2005, 198 (40.24\%) had graduated; 186 (37.8\%) were still studying, with $79(16.05 \%)$ of them intending to graduate in December 2010; $93(18.9 \%)$ had lost and/or given up the grant and $15(3.01 \%)$ had transferred from the institution.

The 198 graduates were invited to answer a research questionnaire. 134 questionnaires were answered, equal to $67.67 \%$. The parameters used for the proposed sampling calculation were satisfied, based on a confidence level of $95 \%$ and assuming a tolerable sample error of 5\%, the desirable sample should have 132 respondents. 
In addition to demographic questions, the questionnaire was developed into sets of questions that corresponded to reference points outlined according to engagement indicators and questions aimed at employability and satisfaction.

The Cronbach Alpha was used to verify the reliability of the reference points outlined according to engagement indicators, since according to Castañeda, Cabrera, Navarro, and De Vries (2010), the reliability analysis can verify the conclusions and estimate a reliability rate for each scale, that is, for each reference point of the engagement construct.

The indicators related to engagement were anchored in three reference points of educational practices: active and collaborative learning; level of academic challenge; and enrichment of educational experiences (Kuh, 2009). For each reference point is a corresponding set of questions. For the set that contemplates the active and collaborative learning reference point, Cronbach's Alpha was 0.56. The questions that are part of the level of academic challenge reference point presented an Alpha corresponding to 0.83, representing a high degree of reliability. However, the Alpha corresponding to the questions that are part of the enrichment of educational experiences reference point was 0.1 , representing a low degree of reliability (Porter, 2011).

Secondary data of students' grade point averages and academic performances were also observed, upon carrying out an analysis of their academic transcripts. The constructs and indicators of engagement, employability, satisfaction, academic performance and grade point average, which are directly linked to engagement, were submitted to a correlation analysis. The academic performance and grade point average are presented in the transcripts of each graduate, such that the overall academic performance average and grade point average could be carried out.

Descriptive frequencies of race, age group and area of knowledge were carried out to contextualize the sample. Salary and satisfaction were compared between men and women in the sense of identifying possible differences in results, according to the gender of those interviewed. Performance averages and grade point averages were compared using the Student's t-test (for independent samples). Three significance criteria were adopted. Tests with a significance less than or equal to $0.05(\mathrm{p} \leq 0.05)$ were considered statistically significant; tests greater than 0.05 and less than or equal to $0.075(0.05<\mathrm{p} \leq 0.075)$ were considered to have a moderate statistical significance; and those greater than 0.075 and less than or equal to $0.1(0.075<p \leq 0.1)$ were considered to have a low statistical significance. For the significances adopted, three lines were considered in figures 1, 2 and 3 of this paper. A thick line $(-$ ) was used to represent a statistical significance, a thin line $(\overrightarrow{)})$ to represent a moderate significance and a dotted line (.....) to represent low significance. All statistical analyses were carried out using the SPSS - Statistical Package for the Social Sciences 16.0 - 2007. According to Bós (2004), p values greater than 0.05 and less than 0.1 are considered indicative of significance. In this paper, this classification was adapted, using moderate to low significance.

\section{Analysis and Discussion of Results}

Of the 134 respondents, $32(23.9 \%)$ are male and 102 (76.1\%) are female. These data are compatible with those presented in the Higher Education Census Technical Brief of 2009, which presents Brazilian Higher Education as predominantly consisting of females (INEP/MEC/DEED 2010). SisProUni (2011) reveals that $51 \%$ of the ProUni scholarships are allocated to female students. Regarding women's education, the Annual Report on Racial Inequality in Brazil, during the 2007 - 2008 period, points out that from 1995 to 2006, women had higher rates of education than men, in the white color or race group, as well as in the African or mixed color or race (Paixão \& Carvano, 2008).

The graduates identified themselves regarding race as follows: $119(88.8 \%)$ white, $10(7.5 \%)$ mixed race, 3 $(2.2 \%)$ African, $1(0.8 \%)$ Asian and $1(0.8 \%)$ Indigenous. These percentages are also compatible with those presented by the Brazilian Institute of Geography and Statistics (IBGE, 2011) for 2009, which states that $48.2 \%$ of the Brazilian population consisted of whites, $44.2 \%$ mixed race, $6.9 \%$ Africans and $0.7 \%$ Asian or indigenous. The same data state that in Rio Grande do Sul, the race of the population corresponds to $81.4 \%$ white, $13.3 \%$ mixed race, $5.0 \%$ African and $0.3 \%$ Asian or indigenous.

With respect to their age when entering the Program, in 2005, 96 (71.6) were 17-20 years old, 28 (20.9\%) were between $21-30,5(3.7 \%)$ between $31-40,4(3 \%)$ between $41-50$ and $1(0.8 \%)$ more than 50 years old. The $71.6 \%$ percent of graduates who entered college between 17-20 years is compatible with that intended by the goals of the National Education Plan (PNE) - 2011-2020 decade, which has established as one of its goals to increase the gross rate of higher education enrollments to $50 \%$ and the net rate to $33 \%$ in the 18 to 24 year old population, ensuring the quality of the offer (Brasil, 2011). 
Regarding the main degree areas, the largest percentage of graduates is from programs in the Applied Social Sciences with $63(47.0 \%)$, followed by those in the Human Sciences with 25 (18.7\%), Health Sciences 18 (13.4\%), Engineering and Technologies 9 (6.7\%), Linguistics - Letters and Arts with 8 (6.0\%) and Exact and Earth Sciences with 5 (3.7\%) graduates.

These data are compatible with the data regarding the ten undergraduate programs that had the highest rates of enrollment in 2009, among which four are from the Applied Social Sciences, with Administration and Law having the highest percentages, $18.5 \%$ and $10.9 \%$, respectively (INEP/MEC/DEED, 2010).

Of the 134 graduates, $123(91.8 \%)$ were working at the time of the this research. Of those who were working (see Table 1), more than 65\% worked in the area of their degree. Of the rest, $11(8.2 \%)$ correspond to 1 man, who is studying for a master's degree and 10 women, of whom 3 are studying for their master's degree, 2 in a new higher education course and 5 are not studying or working.

The majority of the respondents who are working, that is, $90(73.2 \%)$ of the 123 would study the same degree if they could start over. The proportion of respondents who would study the same program again is significantly greater in those who are working in the area of their degree (80.2\%) than those who are not working in the area of their degree $(59.5 \%, \mathrm{p}=0.014)$. This means that there is a relation between the current job and academic education. The reciprocity between degree and job area have been related to job satisfaction (De Vries et al. 2008).

Table 1. Current work related to academic education and studying the same degree

\begin{tabular}{|c|c|c|c|c|c|c|c|c|}
\hline \multirow{4}{*}{ Current work is related to academic education } & \multicolumn{8}{|c|}{ Study the same degree } \\
\hline & \multicolumn{3}{|c|}{ Definitely yes; Probably yes } & \multicolumn{3}{|c|}{$\begin{array}{l}\text { Definitely not; } \\
\text { Probably not }\end{array}$} & \multicolumn{2}{|c|}{ Total } \\
\hline & \multicolumn{3}{|c|}{ Frq. } & \multicolumn{3}{|c|}{ Frq. } & Frq. & $\%$ \\
\hline & Male & Female & Subtotal & Male & Female & Subtotal & & \\
\hline Yes & 18 & 47 & 65 & 6 & 10 & 16 & 81 & 65,85 \\
\hline No & 3 & 22 & 25 & 4 & 13 & 17 & 42 & 34,15 \\
\hline Total & 21 & 69 & 90 & 10 & 23 & 33 & 123 & 100 \\
\hline
\end{tabular}

Note. Frq. $=$ Frequency.

Becoming established in the job market after graduating is a challenge, mainly with respect to associating one's degree with the job. The results presented here point towards the success of the graduates in getting a job related to their academic education. Associating education with work, according to De Vries, Cabrera, Vazquez, and Queen (2008) are relevant aspects in considering the success of the graduate. In addition to observing the success of the Higher Education graduate, this association allows for the evaluation of the Program's success. In providing them with the opportunity of higher level education, the job market thus assimilated the Higher Education graduates via ProUni.

The large percentage of graduate respondents working may represent a better placement in the job market, since the majority (58.2\% of the 134) of those who worked during the course of their studies is not in the same job as when they were studying. These results are compatible with a study carried out by the Brazilian Institute of Opinion and Statistics - Ibope survey with 1200 recent graduates with full scholarships from the University for All Program, at the request of the Ministry of Education, from March 13 to 23 of 2009. The Ibope survey revealed that $80 \%$ of the graduates were already working, though it did not identify whether these graduates were working in the area of their education (Brasil, 2009). However, the results presented in the present paper, in addition to pointing out whether the graduates were working or not, also noted that more than $65 \%$ of the working graduates were working in their area of education. Working in one's area of education represents the absorption of these professional by the job market, satisfying demand.

Observe in Table 2 the salary of the graduates. One of the respondents, though not working, but studying for a master's degree, indicated the study grant as the salary. The highest percentage of the 124 respondents corresponded to $46.0 \%$, with a salary of up to $\mathrm{R} \$ 1,020.00$. The respondents with a salary between $\mathrm{R} \$ 1,021.00$ and $\mathrm{R} \$ 2,040.00$ represented $42.7 \%$. Only $4 \%$ indicated having an income which varied from $\mathrm{R} \$ 2,041.00$ to $\mathrm{R} \$ 3,061.00$; the remaining $7.3 \%$ have a salary higher than $\mathrm{R} \$ 3,061.00$. 
Table 2. Salary of the respondents

\begin{tabular}{lcccccc}
\hline \multirow{2}{*}{ Salary } & \multicolumn{2}{c}{ Male } & \multicolumn{2}{c}{ Female } & \multicolumn{2}{c}{ Total } \\
\cline { 2 - 7 } & Frq. & $\%$ & Frq. & $\%$ & Frq. & $\%$ \\
\hline Up to R\$1,020.00 & 12 & 38.71 & 45 & 48.39 & 57 & 45.97 \\
From R\$ 1,021.00 to R\$ 2,040.00 & 12 & 38.71 & 41 & 44.09 & 53 & 42.74 \\
From R\$ 2,041.00 to R \$ 3,060.00 & 1 & 3.23 & 4 & 4.30 & 5 & 4.03 \\
More than R\$ 3,061.00 & 6 & 19.35 & 3 & 3.23 & 9 & 7.26 \\
Total & 31 & 100 & 93 & 100 & 124 & 100 \\
\hline
\end{tabular}

Note. Fr.=Frequency.

Observe that in more than half $(42.7 \%+4 \%+7.3 \%=54.0 \%)$ of the respondents, the individual salary is above two minimum salaries, that is, above $\mathrm{R} \$ 1,020.00$. One of the conditions required for receiving a ProUni scholarship is a per capita monthly household income of up to 1 (one) and $1 / 2$ (half) minimum salaries for full scholarships. For partial scholarships, the per capita monthly household income cannot exceed the value of up to 3 (three) minimum salaries. One can infer here that the current financial situation of the respondent graduates is better than their situation when they were entering academic life, since they all had a full scholarship, thus their per capita monthly household income was less than $\mathrm{R} \$ 765.00$. Though this value is far from the minimum salary necessary estimated by the Inter-union Department of Statistics and Socioeconomic Studies (Dieese), this can be explained due to the initial per capita household income upon entering college, and the same goes for the $46 \%$ with a monthly income of up to $\mathrm{R} \$ 1,020.00$, since the income indicated by the respondents is individual and not per capita household.

With respect to current job satisfaction (Table 3), observe that the majority are in the scope of those satisfied, $72.4 \%$, while $27.6 \%$ consider themselves to be dissatisfied. Even those graduates who were not working answered this question, which totaled 134. This can be explained by the fact that 6 of the 11 who were not working were continuing their studies in their degree area. However, no reason was found for the 5 people who were not working to answer this question, since it was clear: Are you satisfied with your current job? The high percentage of satisfied respondents is an excellent indicator of success, since it reflects the non-monetary as well as monetary rewards (Vila, García-Aracil \& Mora, 2007). This statement by Vila, García-Aracil and Mora (2007) is pertinent, since upon comparing the $46 \%$ percent of the respondents with a salary of up to $\mathrm{R} \$ 1,020.00$ with the percentage of satisfied respondents, $72.4 \%$, one can conjecture that satisfaction involves aspects beyond salary. This can also be justified by the fact that the salary of up to $\mathrm{R} \$ 1,020.00$, attributed to the graduate, may be adding to the per capita monthly household income.

Table 3. Current job satisfaction

\begin{tabular}{lccccccc}
\hline \multirow{2}{*}{ Level of satisfaction } & \multicolumn{2}{c}{ Male } & \multicolumn{2}{c}{ Female } & \multicolumn{2}{c}{ Total } \\
\cline { 2 - 7 } & Frq. & $\%$ & Frq. & $\%$ & Frq. & $\%$ \\
\hline Partially and/or completely dissatisfied; Not satisfied or dissatisfied & 8 & 25 & 29 & 28.43 & 37 & 27.61 \\
Partially satisfied; Completely satisfied & 24 & 75 & 73 & 71.57 & 97 & 72.39 \\
Total & 32 & 100 & 102 & 100 & 134 & 100 \\
\hline
\end{tabular}

Note. Frq. $=$ Frequency.

In Table 4, there are correlations carried out between satisfaction, current salary and studying the same degree, if they could start their academic life over again. There was a positively significant correlation between satisfaction and salary at $\mathrm{p}=0.001$. This means that the probability of the level of satisfaction and salary not being correlated is very small. It could not be any other way, seeing that the per capita monthly household income of the graduates upon entering college was up to $\mathrm{R} \$ 765.00$, whereas now, as graduates, they have an individual salary that collaborates towards increasing their per capita monthly household income.

The correlation between satisfaction and starting the same degree over was also significant at $\mathrm{p}=0.004$. This positive correlation represents an accomplishment by the respondents with the education achieved, also indicating the importance that the graduates are placing on their academic education, taking advantage of the 
investments of the University of All Program.

The correlation between salary and starting the same degree over was $\mathrm{p}=0.006$. This result indicates that the degree achieved and the salary resulting from it made the investments of ProUni in the education of people from minority groups worthwhile, since it leads to the placement of a new graduate profile in the job market, thus improving their life conditions.

Table 4. Correlations between satisfaction, current salary and studying the same degree

\begin{tabular}{|c|c|c|c|c|}
\hline & Satisfaction & Current salary & Studying the same degree & \\
\hline & 1.000 & 0.429 & 0.248 & Pearson Correlation \\
\hline \multirow[t]{3}{*}{ Satisfaction } & & 0.001 & 0.004 & Sig. (2-tailed) \\
\hline & 134.000 & 134 & 134 & $\mathrm{~N}$ \\
\hline & 0.429 & 1.000 & 0.236 & Pearson Correlation \\
\hline \multirow[t]{3}{*}{ Current salary } & 0.001 & & 0.006 & Sig. (2-tailed) \\
\hline & 134 & 134.000 & 134 & $\mathrm{~N}$ \\
\hline & 0.248 & 0.236 & 1.000 & Pearson Correlation \\
\hline \multirow[t]{2}{*}{ Studying the same degree } & 0.004 & 0.006 & & Sig. (2-tailed) \\
\hline & 134 & 134 & 134 & $\mathrm{~N}$ \\
\hline
\end{tabular}

Source: Felicetti (2011, 2014). Note. $\mathrm{N}=$ Number/Total.

The values of the performance averages and grade point averages are presented in Table 5. The performance grade of each student was calculated among all the students from different semesters and programs, varying from 0 to 10 . The average performance among the respondents was 6.51 . However, the grade point average varied from 0 to 4, with the respondents having an average of 2.99. Since the two averages are calculated differently, it is not possible to compare them despite the academic performance being $65 \%$ of the maximum value and the grade point average representing $75 \%$ of the maximum value.

Table 5. Academic performance and grade point average of the respondents

\begin{tabular}{ccccccccccc}
\hline \multicolumn{2}{c}{ Respondent Graduate } & \multicolumn{3}{c}{ Academic Performance } & \multicolumn{4}{c}{ Grade Point Average } \\
\hline Sex & $\mathrm{N}$ & $\%$ & Avg. & $\begin{array}{c}\text { Stand. } \\
\text { Dev. }\end{array}$ & Max. & Min. & Avg. & $\begin{array}{c}\text { Stand.De } \\
\text { v. }\end{array}$ & Max. & Min. \\
\hline Male & 32 & 23.88 & 6.50 & 0.21 & 6.89 & 5.90 & 2.81 & 0.53 & 3.75 & 1.83 \\
\hline Female & 102 & 76.12 & 6.51 & 0.29 & 7.61 & 5.45 & 3.04 & 0.46 & 3.87 & 1.61 \\
\hline Total & 134 & 100.0 & 6.51 & 0.27 & 7.61 & 5.45 & 2.99 & 0.48 & 3.87 & 1.61 \\
\hline
\end{tabular}

Note. $\mathrm{N}=$ Number/Total, Avg=Average, Stand. Dev.=Standard Deviation, Max=Maximum, Min. $=$ Minimum

Academic performance and grade point average were analyzed together with employability, satisfaction and the engagement indicators (active and collaborative learning, level of academic challenge, enrichment of educational experiences), since grade point average as well as performance can be indicative of engagement, employability and satisfaction.

Observe in figure 1 that there was a statistically significant correlation between grade point average and academic performance at $\mathrm{p}=0.001$. There was also a statistically significant correlation between the grade point average versus satisfaction at $\mathrm{p}=0.014$. Active and collaborative learning versus enrichment of educational experiences also presented a statistically significant correlation at $\mathrm{p}=0.030$, which indicates that greater participation in active and collaborative learning is related to greater enrichment of educational experiences. Active and collaborative learning and the level of academic challenge had a p of 0.001 , that is, a statistically significant correlation indicating that active and collaborative learning versus academic challenge have a positive correlation. The correlation between the higher level of academic challenge and the greater enrichment of educational experiences was statistically significant at $\mathrm{p}=0.026$, also indicating that the level of academic challenge versus enrichment of educational experiences are correlated. There was also a statistically significant 
correlation between greater employability and greater satisfaction at $\mathrm{p}=0.001$.

The statistically significant correlations presented between satisfaction and grade point average, satisfaction and employability may indicate the affinity existing between the results obtained in grade point average and work. This affinity is linked to the education developed and acquired by the graduates and, by extension, job satisfaction. These correlations are compatible with what De Vries, Cabrera, Vazquez and Queen (2008, p. 73) write: "satisfaction is related to the congruence between the degree and the job".

There was a moderately significant correlation between active and collaborative learning and employability at $\mathrm{p}=0.071$. There was a low significant relation between enrichment of educational experiences and satisfaction at $\mathrm{p}=0.099$.

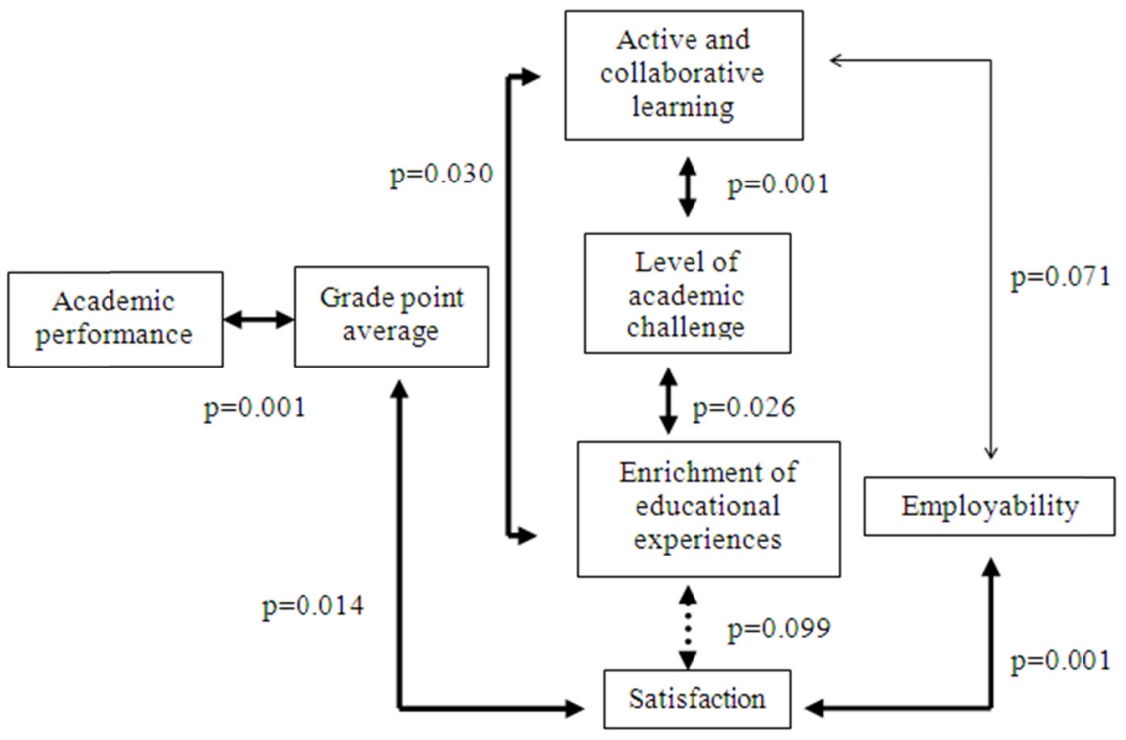

Figure 1. Relation between indicators of engagement, employability, satisfaction, grade point average and academic performance

Note. A thick line represents a statistical significance, a thin line represents a moderate significance and a dotted line represents a low significance.

The moderately significant and low significant correlations can be explained due to the size of the sample. One may also infer that the relations with moderate and low significances presented in this study may be due to the adaptation of the questions that contemplate the reference points of the engagement indicator. This can be explained by the low Cronbach's Alpha found in two of the reference points and, though one of the reference points (level of academic challenge) had presented an Alpha of 0.83 , there was no statistically significant relation between this reference point and employability and satisfaction. This suggests the need for larger studies to constitute the indicators that compose the constructs thus improving the degree of reliability of the Cronbach Alpha.

The analysis of the correlation between the indicators of engagement, employability, satisfaction, grade point average and academic performance according to gender was also carried out. What stood out in this analysis was the statistically significant correlation for females between the indicators of engagement, employability, satisfaction, grade point average and academic performance. The statistical significances were between: active and collaborative learning versus level of academic challenge at $\mathrm{p}=0.001$; grade point average versus satisfaction at $\mathrm{p}=0.010$; grade point average and employability at $\mathrm{p}=0.037$; and grade point average versus academic performance at $\mathrm{p}=0.001$; and, between satisfaction versus employability at $\mathrm{p}=0.001$. On the other hand, the men did not present any significances, which can be related to the low number of male respondents, explaining the moderate and low significances found in the overall analysis.

\section{Conclusions}

Student engagement in their education appears to be reflected in their employability and their job satisfaction. This was proven through the statistically significant correlation between: satisfaction and salary and studying the same degree over again if they could, due to the large number of graduates satisfied with their current job and the 
majority of graduates working in their area of education.

Working in one's area of education can be an indication of an academic education capable of meeting the demands of the job market. In other words, this means that in addition to the development of competences specific to each area, the set of personal characteristics are also developed. This represents a dedication to one's studies; it represents student engagement in their learning and in their professional development, since job satisfaction is associated to the personal development of each worker.

To claim that they would study the same degree over again if they could is an indication of satisfaction, accomplishment and being able to perform competently in their area of education. Satisfaction is reflected in non-monetary and monetary rewards.

What the data indicate is that by going to University, the ProUni graduates went beyond commitment as students or as scholarship holders. They were academics engaged in their learning, since the result of a quality education is reflected in the job acquired, in one's satisfaction with the education and job.

\section{Acknowledgments}

The research was funded by Coordenação de Aperfeiçoamento de Pessoal de Nível Superior (CAPES).

\section{References}

Anaya, G. (1996). College experiences and student learning: The influence of active learning, college environments, and cocurricular activities. Journal of College Student Development, 37(6) 611-622.

Arthur, L. et al. (2008). The context of higher education and employment: comparisons between different European countries. Centre for Higher Education Research and Information. The Open University. London, 2008. Retrieved from http://www.hefce.ac.uk/pubs/rdreports/2008/rd22_08/rd22_08_2.pdf

Astin, A. W. (1984). Student involvement: A development theory for higher education. Journal of College Student Personnel, 25(2) 297-308.

Baxter, M., \& Magolda, B. (1992). Cocurricular influences on college students' intellectual development. Journal of College Student Development, 33, 203-213.

Booth, W. C., Colomb, G. C., \& Williams, J. M. (2000). A arte da pesquisa. São Paulo: Martins Fontes.

Bós, Â. J. G. (2004). EpiInfo sem mistérios: um manual prático. Porto Alegre: EDIPUCRS.

Brasil. (2005). Lei $n^{o} 11.096$, de 13 de janeiro de 2005. Institui o Programa Universidade para Todos - ProUni, 2005. Presidência da República. Brasília, DF: Diário Oficial da União. Retrieved from http://www.planalto.gov.br/ccivil_03/_Ato2004-2006/2005/LEI/L11096.htm

Brasil. (2009). Bolsistas revelam em pesquisa as vantagens da graduação. Retrieved from http://portal.mec.gov.br/index.php?option=com_content\&view=article\&id=13346:bolsistas-revelam-em-pes quisa-as-vantagens-da-graduacao\&catid $=212$

Brasil. (2011). Projeto de Lei no 8035/2010 Aprova o Plano Nacional de Educação para o decênio 2011-2020. Retrieved from http://www.planalto.gov.br/ccivil_03/Projetos/PL/2010/msg701-101215.htm

Cabrera, A. F., Nora, A., \& Castañeda, M. B. (1992). The role of finances in the persistence process: A structural model. Research in Higher Education, 33(5), 571-593. https://doi.org/10.1007/BF00973759

Cabrera, A. F., Nora, A., Terenzini, P. T., Pascarella, E., \& Hagedorn, L. S. (1999). Campus racial climate and the adjustment of students to college: A comparison between White students and African American students. Journal of Higher Education, 70(2), 134-160. https://doi.org/10.2307/2649125

Castañeda, M. B. et al. (2010). Procesamiento de datos y análisis estadísticos utiliando SPSS - Un libro práctico para investigadores y administradores educativos. Porto Alegre: EDIPUCRS.

Chickering, A. W., \& Gamson, Z. F. (1987). Seven Principles for Good Practice in Undergraduate Education. AAHE Bulletin, mar. (pp. 3-7).

Davis, K., \& Newstrom, J. W. (1992). Comportamento humano no trabalho. Uma abordagem psicológica. São Paulo: Pioneira.

De Vries, W. et al. (2008). Conclusiones a Contrapelo. La Aportación de Distintas Carreras Universitarias a la Satisfacción en el Empleo. Revista de la Educación Superior. v. XXXVII(2), 146, Abril-Junio de, 67-84.

DIEESE. (2009). Salário mínimo nominal e necessário n. 10/3/2011. São Paulo.

Evans, N. J. (1987). A framework for assisting student affairs staff in fostering moral development. Journal of 
Counseling and Development, 66, 191-193. https://doi.org/10.1002/j.1556-6676.1987.tb00845.x

Felicetti, V. L. (2011). Comprometimento do estudante: um elo entre aprendizagem e inclusão social na qualidade da Educação Superior. 07 de dezembro de 2011. 298 folhas. Tese de doutorado, Pontifícia Universidade Católica do Rio Grande do Sul, Porto Alegre.

Felicetti, V. L. (2014). Comprometimento do aluno ProUni: acesso, persistência e formação acadêmica. Rev. bras. Estud. pedagog. Estudos RBEP (online), Brasília. https://doi.org/10.1590/S2176-6681/301911955

Felicetti, V. L., \& Morosini, M. C. (2008). O Comprometimento do Estudante com a Aprendizagem - Onde está o Estado da Arte. In. ANPEDSUL - VII Seminário de Pesquisa em Educação da Região Sul. Pesquisa em educação e inserção social. Itajaí: Univali.

Harper, S. R. (2008). Realizing the intended outcomes of Brown: High-achieving African American male undergraduates and social capital. American Behavioral Scientist, 51(7), 1-24. https://doi.org/10.1177/0002764207312004

Harper, S. R., \& Quaye, S. J., (2009). Student Engagement in Higher Education: Theoretical perspectives and practical approaches for diverse populations. New York: Routledge.

Hilsdorf, C. (2008). O que é empregabilidade? Artigo Site Artigonal. Retrieved from http://www.artigonal.com/marketing-pessoal-artigos/o-que-e-empregabilidade-597930.html

IBGE. (2011). Instituto Brasileiro de Geografia e Estatística. Censo 2010: população do Brasil é de 190.732.694 pessoas. Retrieved from http://www.ibge.gov.br/home/presidencia/noticias/noticia_visualiza.php?id_noticia $=1766 \mathrm{INEP} / \mathrm{MEC} / \mathrm{DE}$

Kerlinger, F. (1984). Foundations of behavioral research: educational and psychological inquiry. New York: Holt Rinehart Ed.

Knight, P., \& Yorke, M. (2003). Assesment, Learning and Employability. London.

Kuh, G. D. (2009). The national survey of student engagement: Conceptual and empirical foundations. New Directions for Institutional Research, 2009(141), 5-20. https://doi.org/10.1002/ir.283

Kuh, G. D. et al. (2005). Assessing Conditions to Enhance Educational Effectiveness: The Inventory for Student Engagement and Success. San Francisco: Jossey-Bass.

Menne, J. W. (1967). Techniques for Evaluating the College Environment. Journal of Educational Measurement, 4(4), 219-225. https://doi.org/10.1111/j.1745-3984.1967.tb00590.x

Pace, C. R. (1969). An Evaluation of Higher Education: Plans and Perspectives. https://doi.org/10.2307/1978137

Pace, C. R. (1979). Measuring outcomes of college: Fifty years of findings and recommendations for the future. San Francisco: Jossey-Bass.

Paixão, M., \& Carvano, L. M. (Orgs.). (2008). Relatório Anual das Desigualdades Raciais no Brasil; 2007 2008. Rio de Janeiro: Editora Garamond Ltda.

Pascarella, E. T. (1985). College Environmental Influences on Learning and Cognitive Development: A Critical Review and Synthesis. In J. C. SMART (Ed.), Higher Education: Handbook of Theory and Research. New York: Agathon.

Pascarella, E. T., \& Terenzini, P. T. (2005). How College Affects Students: A Third Decade of Research (v. 2). São Francisco: Jossey-Bass: A Wiley Imprint.

Porter, S. R. (2011). Do college student surveys have any validity? Review of Higher Education, 35(1), 45-76. https://doi.org/10.1353/rhe.2011.0034

Robbins, S. P. (2005). Comportamento Organizacional. São Paulo: Prentice-Hall.

Schomburg, H., \& Teichler, U. (2006). Higher Education and Graduate Employment in Europe: Results of Graduates Surveys from 12 Countries. Dordrecht: Springer.

SISPROUNI. (2011). Bolsistas por região, 2011. Retrieved from http://ProUniportal.mec.gov.br/images/arquivos/pdf/Representacoes_graficas/bolsistas_por_regiao.pdf

Teichler, U. (2007). Careers of University Graduates: Views and Experiences in Comparative Perspectives. Series Higher Education Dynamics.

Tinto, V. (1987). Leaving College: Rethinking the Causes and Cures of Student Attrition. Chicago: University of 
Chicago Press.

Tinto, V. (2000). Taking retention seriously: Rethinking the first year of college. NACADA, Journal, 19(2), 5-10. https://doi.org/10.12930/0271-9517-19.2.5

Torres, V., Howard-Hamilton, M. F., \& Cooper, D. L. (2003). Identity development of diverse populations: Implications for teaching and administration in higher education. ASHE-ERIC Higher Education Report, 29(6). San Francisco: Jossey-Bass.

Tyler, R W. (1949). Basic Principles of Curriculum and Instruction. Chicago: University of Chicago Press.

Vila, L. E., García-Aracil, A., \& Mora, J. G. (2007). The Distribution of Job Satisfaction Among Young European Graduates: Does the Choice of Study Field Matter? The Journal of Higher Education, 78(1), 97-118. https://doi.org/10.1353/jhe.2007.0006

Wolniak, G. C., \& Pascarella, E. T. (2005). The effects of college major and job field congruence on job satisfaction. Journal of Vocational Behavior, 67, 233-251. https://doi.org/10.1016/j.jvb.2004.08.010

\section{Copyrights}

Copyright for this article is retained by the author(s), with first publication rights granted to the journal.

This is an open-access article distributed under the terms and conditions of the Creative Commons Attribution license (http://creativecommons.org/licenses/by/4.0/). 